\title{
FRONTAGE ROADS: AN ASSESSMENT OF LEGAL ISSUES, DESIGN DECISIONS, COSTS, OPERATIONS, AND LAND-DEVELOPMENT DIFFERENCES
}

\author{
By
}

Dr. Kara M. Kockelman

(Corresponding Author)

Clare Boothe Luce Assistant Professor of Civil Engineering

The University of Texas at Austin

6.9 ECJ, Austin, TX 78712

Phone: (512) 471-0210, FAX: (512) 475-8744

kkockelm@mail.utexas.edu

Randy Machemehl

Nasser I. Al-Rashid Professor of Civil Engineering

The University of Texas at Austin rbm@mail.utexas.edu

Aaron W. Overman

Graduate Student Researcher The

University of Texas at Austin

aoverman@usa.net

Jacob Sesker

Graduate Student Researcher The

University of Texas at Austin jsesker25@yahoo.com

Marwan Madi

Graduate Student Researcher The

University of Texas at Austin

marwanfmadi@hotmail.com

Jean (Jenny) Peterman

Transportation Analyst

Austin District Offices

Texas Department of Transportation

jpeterm@dot.state.tx.us

Susan Handy

Associate Professor of City and Regional Planning

The University of Texas at Austin

handy@mail.utexas.edu

The following paper is a pre-print and the final publication can be found in Journal of Transportation Engineering, 129 (3):242-252, 2003. 


\section{ABSTRACT}

A policy of building frontage roads alongside freeway mainlanes avoids the purchase of access rights when upgrading existing highways to freeway standards, and generally supplements local street networks. It also may affect corridor operations, land values, and development patterns. This paper seeks to provide a comprehensive evaluation of frontage road design policies by summarizing research results related to legal statutes affecting public access to roadways, discussing access policies and practices across the states, comparing land development and operations of corridors with and without frontage roads, summarizing studies on access-right valuation, and evaluating construction cost distinctions.

A literature review concluded that a wide variety of options are available to agencies for limiting access to and improving flow and safety along freeway corridors. Statistical analyses of paired corridors suggested that land near frontage roads is associated with lower household incomes, lower population densities, lower percentages of bike trips to work, lower vehicle occupancies for work trips, and higher unemployment rates than those without frontage roads. Lower employment densities along freeway corridors also emerged when frontage roads were present. Operational simulations of various freeway systems demonstrated that frontage roads may improve the operation of freeway mainlanes in heavily developed areas, but not in moderately developed areas (e.g., purely residential). Arterial systems in these simulations were supplemented by frontage roads and thus also performed better in their presence. The financial costs associated with frontage road facilities were found to be considerably higher than those associated with non-frontage road facilities, except in cases of extremely high access-right values. It is hoped that these results, in addition to efforts by other researchers, will assist in constructing a solid, formal policy for all states and regions to follow in providing access along new and existing freeways in the decades to come.

Key Words: frontage roads, access rights, crash frequency, traffic simulation, freeway construction costs, corridor comparisons

\section{INTRODUCTION}

AASHTO's Green Book bills frontage roads as "the ultimate in access control." (1995, p. 528) And, until recently, frontage roads have been Texas's primary design solution to this issue along freeways, where fully 4,514 centerline miles of frontage road presently exist (TxDOT 1999). A policy of building frontage roads avoids the purchase of access rights when upgrading existing highways to freeway standards, and generally supplements local street networks. It also may impact corridor operations, land values, and development patterns. This research investigated frontage roads as an element of limited-access highway design with an objective of providing a comprehensive evaluation of frontage road design policies. This paper summarizes the research effort by reviewing legal statutes affecting public access to roadways, summarizing access policies and practices across the states, comparing land development and operations of corridors with and without frontage roads, summarizing studies on access-right valuation, and evaluating construction cost distinctions. 
In the first year of this two-year study, an extensive literature review was conducted in order to ascertain the current legal attitudes and operational strategies involving frontage roads across the U.S. This information is presented first here, to place this work in its proper context. Subsequent sections detail results of investigations into design policies, corridor land development, frontage road safety, corridor operations, and comprehensive construction costs. The report concludes with an overall assessment of the competing factors and recommendations as to design policies. Due to space constraints, only key results are presented here; for additional information, readers may care to consult the full report by Kockelman et al. (Forthcoming) and/or earlier reports by Kockelman et al. (2001), Overman (2000), Madi (2001), and Peterman (2000).

\section{LEGAL BACKGROUND AND LITERATURE REVIEW}

A summary of relevant laws are presented here, providing a legal background on the provision of landowner access to the public property of highways. This discussion is extended to the valuation of access rights and damages warranted when a property's access is removed. Information on access management and corridor preservation suggests a variety of strategies that may eliminate many future landowner and road authority conflicts before they can arise. Lastly, a section on the operational advantages and disadvantages of frontage roads as well as specific design recommendations from the literature provides some insight into the performance of these systems in different situations.

English common law was one of the first written documents delineating the rights of property owners whose land abutted a public roadway (FHWA, 1976). The first roadway network in the United States to fully limit access along its length was the system of Interstate and Defense Highways. In fact, a 1944 congressional study leading to the Federal-Aid Highway Act, which founded the Interstate system, strongly recommended that states pass laws permitting them to either pay damages for access lost or provide an alternate means of access (Netherton, 1963). To control access, some states chose to purchase access rights with the acquisition of parts of each parcel, while others purchased large tracts of land on either side of the Interstate, essentially circumventing access issues. In 1961 AASHO called for access control on all of the Interstate system, either by "acquiring access rights outright prior to construction or by the construction of frontage roads or both" (AASHO, 1961, p. 3). Acquisition of the necessary right-of-way had been recognized as a problem well before Interstate construction ever began. Many states did not have statutory authority to purchase rights-of-way prior to highway construction. A major step in getting the highways built was the 1956 Highway Act, which allowed the U.S. Secretary of Commerce to acquire land and/or access for any state to build its sections of the Interstate Highway system (AASHO, 1961, p. 4).

Major issues arose when Interstate highways were located over existing highways where access had not previously been controlled or limited. In these situations, it was deemed that abutting landowners were entitled to access rights. States then had several choices for providing this access. One was to use the existing highway as a frontage road, allowing access along the outer edge and purchasing enough right-of-way on the opposite side of the freeway to build another frontage road. Another solution was to purchase the entire parcel of land, thus removing the property owner's right of access (AASHO, 1961). This second solution was used most often in urban and suburban areas, since access rights were felt or found to be such a significant part of the property's value. There also was the option to purchase all the property between streets or alleys parallel to the freeway corridor, and using these streets or alleys as frontage roads 
(AASHO, 1961). A rarely used strategy involved the state purchasing only the access rights to the property while not acquiring any actual land. This situation was useful in rural areas where land values were not so closely tied to access because they had residual value as agricultural properties.

Two polices related to right-of-way acquisition are the "enhanced value" deduction and the early-take procedure, and both may assist in corridor preservation. Under an enhanced-value policy, the state subtracts any value added to the remaining portion of a parcel due to highway construction from any amount awarded for the actual takings on the parcel before compensating for land takings. Currently, twenty-four states have laws that allow it (Texas Performance Review, 1991, p. 55; Bass et al. 1996). More common techniques include fee simple purchase (acquiring full ownership of the property), negotiated agreements (a form of fee simple purchase where the purchase takes place through a contractual arrangement instead of eminent domain), protective buying (purchasing land in advance of final project approval when development threatens to obstruct the right of way), eminent domain (taking private property for public use by condemnation or regulation and compensating the prior owner), and donations (owners voluntarily donate land to the state; the state can then use the fair market value of the property toward matching shares in federal aid highway projects).

Access to highways in new locations has also led to controversy. 'Remainders' are small pieces of land left over after highway construction divides a property. Guidelines in the 1950s allowed a state to choose one of the following remedies: build frontage roads to connect remainders to public highways, provide continuity in a system of existing roads, or reestablish connection between two portions of a property severed by the new highway (AASHO, 1961). Although courts have ruled that property owners do not retain rights of access to highway facilities on entirely new locations, they often have sided with the property owners in cases where there was a combination of old and new right-of-ways used (Netherton, 1963).

A landowner's right to access is not absolute in some legal opinions. "This right [of the property owner to protected right of access] does not encompass the right to access the public road at any and all points along the boundary between his property and the road.... Thus, the property owner's right of access is restricted to the right of reasonable access" (Vance, 1988, N346). A property owner must be provided with substitute and reasonable access to the roadway; this may be via a frontage road or some other road connecting his or her property to the new highway. The state must ensure that this substitute access does not substantially impair the former right of access; otherwise, the state may be liable for damages. Frontage road construction is argued to provide reasonable access, and the landowner is due no compensation when a frontage road is constructed and other access removed, as long as the frontage road connects to the new highway within a reasonable distance (Teacher's Insurance and Annuity Association of America v. City of Wichita, 221 Kan. 325, 559 P.2d 347). However, the definition of what is reasonable remained an issue for some time in the courts, and varied on a state-bystate and sometimes ruling-by-ruling basis. In general, one-quarter to one-half (0.25-0.5) miles of additional travel distance has been considered the limit of "reasonable." (See, e.g., Wis.2d 511, 109 N.W.2d 71; State ex rel. Herman v. Schaffer in Arizona; Florida DOT and Pinellas County v. ABS, Inc., 1976; Kansas's Brock v. State Highway Commission, 1965, and Ray v. State Highway Commission, 1966; Minnesota's State v. Gannons, Inc., 1966; Nebraska's Berlowitz v. State Department of Roads, 1966; New Mexico's State ex rel. State Highway Commission v. Silva, 1962; Arizona's State ex. rel. Herman v. Jacobs, 1968; California's People by Department 
of Public Works v. Renaud, 1961; Nebraska's State ex rel. Department of Highways v. Linnecke, 1970; and Vance, 1988.)

The amount of landowner compensation required when unreasonable access is imposed is the "difference in market value of the affected property immediately before and after the impairment of access occurs, based on the highest and best use of the property before and after the damage takes place" (Vance, 1988, N355). Westerfield (1993) and Gallego (1996) used regression models to estimate the value of removed access rights, using data on settlements paid for the rights of access in Texas. (These values are used in the cost computations and comparisons made in the final section of this paper.) Damages due to traffic diversion such as fewer vehicles flowing past the property and their impact on business revenues are generally excluded, because the "abutting owner has no right to the continuation of a flow of traffic in front of his property.... The owner of abutting land has no property right in the traveling public using the highway" (Kansas's Brock v. State Highway Commission, 1965). Other court decisions mirror this decision (e.g., Arkansas State Highway Commission v. Bingham, 1960; California's People v. Becker, 1968; and Idaho's James v. State, 1964). These prior legal decisions are likely to be important for state transportation policy, because many property owners will make such an argument in favor of ramp installation or bypass avoidance.

Research conducted to reveal the effects of highway projects on land values has potential implications for estimating the amount of damages to be awarded landowners. This valuation can be very important in weighing the costs of building access via frontage roads versus paying landowners for the outright removal of access. Investigations of several highway corridors show that frontage roads can positively impact the price of adjacent land. (See, e.g., Lemley, 1956.) However, when all access-related land value changes are taken into account, some highway construction may result in an overall economic loss to certain land uses, particularly those that place a high value on quiet and clean air (Williams 1993). The impact a roadway has on land values also depends on its design. Lewis et al. (1997) developed models to estimate the social, economic, and environmental effects of depressed and elevated freeways using examples from Lubbock, Dallas, Houston, and San Antonio. Values tended to rise to pre-construction levels approximately five years after construction, and land values in some cities (especially those with strong controls on land use) kept rising past their pre-construction levels (Tomassik, 1987).

Access management and corridor preservation are two forms of policy critical to longterm control of access with or without frontage roads. Corridor preservation is a series of steps that state highway departments can use to gain control of or protect the right of way for planned transportation facilities. When used during a project's planning stages, corridor preservation can eliminate access issues and perceived needs for frontage roads. AASHTO-listed techniques for corridor preservation include government inducements, such as transferring the right to develop to other locations through planning agencies and use of police powers to acquire land and control access. Land acquisition may include the application of purchase options, exercise of eminent domain, and use of surplus government-owned land (AASHTO, 1990).

Access management involves restricting certain types of access while promoting others. Highways with properly managed access and signalization have been found to carry up to 30 percent more traffic than those without (AASHTO Quarterly, 1992, p. 5). Justice Scalia of the U.S. Supreme Court had agreed that prevention of excessive congestion falls within the realm of exercising police power: “...the common zoning regulations requiring subdividers to observe lotsize and setback restrictions, and to dedicate certain areas to public streets, are in accord with our 
constitutional traditions because the proposed property use would otherwise be the cause of excessive congestion... (Williams and Forester, 1996, p. 25).

Developing large frontage parcels to reduce the number of access points needed and shifting access points to the rear of the properties rather than allowing these along the main road are two strategies found useful in Australia (Westerman, 1990). Based on their review of state codes and practices, Williams et al. (1994) summarized regulatory access-management techniques as including regulating driveway spacing, sight distance, and corner clearance; restricting the number of driveways per existing parcel on developing corridors; increasing the minimum lot frontages along thoroughfares; encouraging joint access and parking lot cross access; reviewing lot splits to prevent access problems; regulating flag lots and lot width-todepth; minimizing commercial strip zoning and promoting mixed use and flexible zoning; regulating private roads and requiring maintenance agreements; establishing reverse frontage requirements for subdivision and residential lots; requiring measurement of building setbacks from future right-of-way line; and promoting unified circulation and parking plans.

Frontage road design policy is tightly linked to access management. Ramp spacing (to freeways), driveway density, and weaving lengths are important topics in this area. For example, Fitzpatrick et al. (1996) have noticed that most drivers required between 60 and 120 meters to weave from an exit ramp to the right-most lane on a two-lane frontage road. The field information also suggested that queues of 90 meters or more at the exit ramp had significant effects on drivers attempting to make the two-sided weaving operation. Based on these results, they recommended that a minimum of 150 meters of exit ramp-to-intersection spacing be provided.

The number of driveways and unsignalized intersections per mile - termed "access density" - and their rate of use (in vehicles per hour) substantially impact frontage road operations. According to Fitzpatrick et al. (1996), this is particularly true when these exceed 16 access points per mile (acc/mi) on one-way frontage roads or $20 \mathrm{acc} / \mathrm{mi}$ on two-way frontage roads. These access-point densities correspond to driveway spacings (on center) of 330 feet and 264 feet, which are much larger than those generally observed in developed corridors. Sound and strong access policies may be critical to corridor success.

As summarized here, legal issues involving frontage roads span a variety of areas. Provision of landowner access to adjacent public property is key, along with the valuation of access rights when this right is removed or access becomes unreasonable. Access management and corridor preservation strategies in other states provide guidance for models well suited for implementation within TxDOT. Design issues are also of importance. More information on the practices of other states follows in the next section, which summarizes survey responses across a variety of State Departments of Transportation.

\section{DOT SURVEY SYNOPSIS}

A survey of state DOTs was undertaken for this project. The survey was distributed in March 2000 to contacts at thirty two state departments of transportation nationwide, and 19 states' officials responded. The survey asked about the agencies' and individuals' 'overall impression of frontage roads", written policies, access provision following highway conversion to freeway standards, and methods of access valuation. The responses from state DOT representatives of Massachusetts, Michigan, North Carolina, Pennsylvania, South Carolina, Virginia, and Vermont were considered to be favorable, because each of these representatives 
mentioned the benefits of frontage roads in their response. Their reasons included the ability of frontage roads to serve local traffic and keep it from congesting the freeway mainlanes, move traffic during crash situations on the mainlanes, provide advantageous access to development, and improve safety by limiting access to the mainlanes by eliminating turning movements and driveways on them.

California, Kansas, Nebraska, Montana, and Virginia representatives mentioned the necessity of providing frontage roads in certain situations, mostly to provide access to otherwise landlocked properties or where access without a frontage road would be circuitous. Frontage roads also are sometimes necessary to restore continuity to local street systems after construction of a fully controlled-access facility.

Survey respondents listed many drawbacks to the use of frontage roads. Four states specifically mentioned the high construction costs of frontage roads as a primary reason that their state does not build many of them. (This concern is supported by the construction cost comparisons provided in the final section of this report.) Environmental impacts were also listed. Other areas of concern were the distances between ramps and intersections, as well as the distance between the frontage road and mainlanes. There was a general trend in all responses in this area that when ramps and intersections are located too near to one another (or where the frontage road and mainlanes are not separated by enough distance) there are ingress and egress problems, and generally poor traffic operations result. Minnesota mentioned a unique solution of providing backage roads, or roads parallel to the freeway that allow development on both sides of the roadway. North Carolina recently started encouraging commercial developers to build access roads behind businesses to provide both visibility to the business from the major road and avoid connecting driveways. A response from Pennsylvania noted that frontage roads could be very confusing for motorists who are not used to their operation. Minnesota favors X-configured interchanges to traditional, diamond interchanges, because they avoid weaving on the mainlanes; however, they require relatively frequent ramp spacing so that connections are not too circuitous.

Most states build all freeways on new locations, so property owners are not entitled to access the new roadway and no frontage road is required. Access is almost always provided by connecting the property to a cross street. When access costs must be paid, most states responded that they simply pay the difference between the appraised cost of the property before and after access is removed, or purchase the entire parcel if it will lack alternate access.

Texas design policy states that frontage roads may be included to restore circulation of local traffic, to unlandlock parcels whose values equal or exceed the frontage road costs, and/or when appraised damages without such roads or economic benefits with such roads exceed the cost of their provision. (TxDOT 1984, pg. 4-77) Similarly, California's policy documents suggest that the construction of frontage roads is justified if their cost is less than severance damages or land acquisition costs. Moreover, if there are more than three access points within a short distance, a frontage road may provide a better form of access than access to the mainlanes.

In summary, the survey of state DOTs indicated that a state's tendency to build frontage roads depended both on past access policies within the state, which tend to depend heavily on legislation, and formal policy guidelines that specify the provisions under which a frontage road will be provided. The roadway geometry associated with frontage roads in other states was in many cases quite different from typical Texas designs. Designs enabling development along on both sides of the frontage roadway was common to several states, generous ramp-to-signal 
distances were required by several, and development adjacent to the ramp-frontage road interface was generally much more restricted than in Texas - in order to prevent dangerous weaving maneuvers.

\section{CASE STUDIES}

An analysis of case study sites from the Austin metropolitan region was undertaken as part of this work to illuminate a number of factors. Primarily, the data collection effort was geared toward establishing a link between crash/injury experience at each of the sites and variables such as vehicle miles traveled, access density, and the incidence of speeding. But site visits also provided valuable information on variety present in adjacent land development and access design decisions.

The twelve case study locations represent a cross-section of frontage road treatments and conditions in the Austin region, and range from a dense urban core location with no real access control, to outlying developing suburban locations utilizing more stringent access controls. Crash and injury counts for the 12 sections of frontage road were compiled from TxDOT records for the January 1995 through September 1999 period; no fatal crashes were reported on any of the twelve sections during that four-year, nine-month period. An "access density" variable was computed as the ratio of access length to overall section length; these ranged from a low of zero (in the case of I-35 at Parmer Lane) to 0.52 (along I-35 at 38 1/2 Street). A Doppler radar device observed off-peak morning speeds providing estimates of each section's $85^{\text {th }}$ percentile speed and its speed variance (i.e., the square of the standard deviation in speeds) ${ }^{1}$. An "incidence of speeding" variable was estimated as the ratio of the $85^{\text {th }}$ percentile speed to the posted speed limit. Collection of two-days traffic count data using pneumatic road tubes took place on a Wednesday and Thursday in mid-August 2000. Multiplying these counts by section length produced estimates of two-day vehicle miles traveled (VMT) on each section (over the two-day count period).

The twelve study sections were the following: U.S. 183 Northbound at Loop 360/Capital of Texas Highway, U.S. 183 Northbound at Balcones Woods Drive, U.S. 183 Northbound at Tweed Court/Riata Trace Parkway, U.S. 183 at Peyton Gin Road, MoPac (Loop 1) Southbound at Capital of Texas Highway, MoPac (Loop 1) Southbound at Steck Avenue, MoPac (Loop 1) Southbound at Anderson Lane/Spicewood Springs/Far West, MoPac (Loop 1) Southbound at Gaines Ranch, Interstate 35 Northbound at Parmer Lane, Interstate 35 Northbound at FM 1325, Interstate 35 Northbound at $381 / 2$ Street, and Interstate 35 Northbound at Onion Creek Parkway. They ranged from having no retail development to over 765,000 square feet of retail space alongside, from having no driveways or intersecting roadways to over 50 percent of the frontage cut out for such access points ${ }^{2}$, from zero to 1500 apartments alongside, and from zero to over 600,000 square feet of office space.

Several sections exhibited nearby cross streets and back-roads that offered viable access options for the abutting developments; such access strategies could be used to moderate or eliminate access along the frontage roads. The I-35 northbound section at FM 1325 in Austin's neighboring city of Round Rock presented the worst design case, offering drivers almost continuous access - if one were willing to drive across the dirt strip that borders the roadway. Ramp and driveway locations are poorly coordinated at this site, presenting serious safety issues. Similarly, at other sections, unnecessarily wide and frequent driveways provided minimal 
channelization of traffic, and certain low-intensity developments had an abundance of driveways (e.g., an adult bookstore at the I-35 northbound section at 38 1/2 Street had fully 4 driveways).

As a first step in investigating relationships among the variables, bivariate scatter plots were produced. These related access density, incidence of speeding, speed variance, and VMT to both crashes and injuries. Positive relationships were noted in all cases; an increase in any of the variables is associated with an increase in injuries and crashes. The most obvious outlier in all cases was at the northbound U.S. 183 at Loop 360 location, which had two exit ramps feeding the frontage road (while all other cases had only one). This unique property could explain the higher levels of injuries and crashes here.

Multivariate linear regression models of crash and injury totals (for the four-year ninemonth period) were estimated using access density, speed variance, and the other explanatory variables described above. Since the sample size in this analysis is extremely small $(\mathrm{N}=12)$, few specifications involving all variables could be tested. Basic linear-in-parameters and linear-invariables models were used.

One problematic instance of (positive) collinearity lay between the incidence of speeding and the variance of speeds. Fortunately, the other variables under study exhibited even less correlation with one another, as shown in Table 1.

Table 1. Correlation Matrix for Explanatory Variables

\begin{tabular}{|l|l|l|l|l|}
\hline & $\begin{array}{l}\text { Access } \\
\text { density }\end{array}$ & $\begin{array}{l}\text { Incidence } \\
\text { of } \\
\text { speeding }\end{array}$ & $\begin{array}{l}\text { Variance } \\
\text { of speeds }\end{array}$ & $\begin{array}{l}\text { VMT } \\
(2 \text { days })\end{array}$ \\
\hline Access density & 1.000 & & & \\
\hline Incidence of speeding & 0.473 & 1.000 & & \\
\hline Variance of speeds & 0.193 & 0.257 & 1.000 & \\
\hline VMT (2 days) & -0.077 & 0.212 & 0.042 & 1.000 \\
\hline
\end{tabular}

Because so few independent variables were available for use in this regression analysis, and because one could reasonably expect each variable to have an effect on both crash and injury occurrence, all four independent variables were included in the initial regressions. The results of these crash and injury regression models are shown in Table 2. Due to the clear lack of statistical significance on the incidence of speeding variable, this was removed from the final model specifications. ${ }^{3}$

Table 2. Variable Coefficients and T-Statistics for 4-Year 9-Month Crash Counts

\begin{tabular}{|l|l|l|l|l|}
\hline & \multicolumn{2}{|l|}{ Initial Models } & \multicolumn{2}{l|}{ Final Models } \\
\hline $\begin{array}{l}\text { Explanatory } \\
\text { variables }\end{array}$ & \#Crashes & \#Injuries & \#Crashes & \#Injuries \\
\hline Constant & -8.195 & 37.473 & -39.851 & -10.770 \\
\hline
\end{tabular}




\begin{tabular}{|c|c|c|c|c|}
\hline & $(-0.119)$ & $(0.692)$ & $(-1.398)$ & $(-0.451)$ \\
\hline Access density & $\begin{array}{l}85.992 \\
(1.207)\end{array}$ & $\begin{array}{l}82.738 * \\
(1.480)\end{array}$ & $\begin{array}{l}65.382 \\
(1.189)\end{array}$ & $\begin{array}{l}51.328 \\
(1.115)\end{array}$ \\
\hline $\begin{array}{l}\text { Incidence of } \\
\text { speeding }\end{array}$ & $\begin{array}{l}-41.245 \\
(-0.511)\end{array}$ & $\begin{array}{l}-62.858 \\
(-0.993)\end{array}$ & (removed) & (removed) \\
\hline $\begin{array}{l}\text { Variance of } \\
\text { speeds }\end{array}$ & $\begin{array}{l}1.020 * \\
(1.814)\end{array}$ & $\begin{array}{l}0.667 * \\
(1.511)\end{array}$ & $\begin{array}{l}0.971^{*} \\
(1.871)\end{array}$ & $\begin{array}{l}0.593 \\
(1.364)\end{array}$ \\
\hline $\begin{array}{l}\text { Vehicle miles } \\
\text { traveled ( } 2 \text { days) }\end{array}$ & $\begin{array}{l}5.092 \times 10^{-3} * \\
(1.828)\end{array}$ & $\begin{array}{l}3.287 \times 10^{-3} * \\
(1.504)\end{array}$ & $\begin{array}{l}4.577 \times 10^{-3} * \\
(1.882)\end{array}$ & $\begin{array}{l}2.503 \times 10^{-3} \\
(1.230)\end{array}$ \\
\hline Adjusted $\mathrm{R}^{2}$ & 0.326 & 0.187 & 0.409 & 0.189 \\
\hline
\end{tabular}

$\mathrm{N}_{\text {obs }}=12$, $\mathrm{t}$-statistics are in parentheses

* Asterisks indicate statistical significance at the $20 \%$ level.

Given such a small $(\mathrm{N}=12)$ sample size, the sample-size-adjusted R-squared values were lessened; moreover, the crash data came from dates prior to the count and speed measurements. However, the crash totals were rather well predicted by the available variables (over $40 \%$ of the variation in crash counts were explained by the model). The coefficients on two-day VMT are consistent with expectations. These coefficients are positive in both cases, and statistically significant at levels of 0.20 (or less). If VMT had been constant for the four-year nine-month period and one assumed that 887 (i.e., $365 \times$ 4.75/2) such two-day periods had occurred over that duration, the parameter values of $4.577 \mathrm{E}-3$ and $2.503 \mathrm{E}-3$ would suggest one crash every additional 189,000 vehicle miles traveled and 1 injury every 346,000 VMT. These crash rates are a little lower than the average crash rates Kweon and Kockelman [Forthcoming] have estimated across all types of driving (which are on the order of one for every 167,000 miles driven), however; it is likely that VMT rose steadily and significantly between 1995 (the first year of crash-data collection) and 2000 (the year the VMT data were taken), since the Austin metro region has experienced substantial population growth and driving. Lower actual VMT for the crash and injury counts analyzed imply even higher coefficients on this variable. Moreover, with access densities higher than zero and with variations in speed, rather standard frontage road sections actually may be more crash- or injury-prone than the "average" road section (which includes local streets and freeways).

As indicated in Table 2 - and as expected, higher access density along a frontage road segment is shown to have a positive effect on both injury and crash occurrence. This variable is statistically significant at the $20 \%$ level in the injury models and a $25 \%$ level in the crash model. Lowering the access density along a frontage road segment via access management strategies can reasonably be expected to reduce the occurrence of both crashes and injuries: moving it from 0.5 to 0.0 , as evident in the maximum and minimum data set values, is expected to yield 33 fewer crashes and 26 fewer injuries over a four-year nine-month period (so 6.9 fewer crashes and 5.5 fewer injuries per year). Finally, variance of speeds contributes to crashes and injuries, as one would expect. Strategies to reduce speed variance, such as separating ramps and driveways by a sufficient distance and stopping vehicles from making drastic speed changes while accessing driveways and ramps along frontage roads, can be expected to reduce the incidence of crashes and injuries. 


\section{CORRIDOR PAIR ANALYSIS}

A common perception of frontage roads is that they encourage commercial development of moderate to high intensity alongside freeway corridors, rather than concentrating such development at major intersections. Such strip development may buffer remaining land uses from the noise and visual impacts of frontage roads, but it also may encourage automobile dependence and/or sprawl. To examine these questions statistically, pairs of frontage road and non-frontage road corridors were found from an atlas of maps. This search for pairs of proximate corridors resulted in 13 pairs of data points, falling in five different states (Texas, Minnesota, Arizona, New Mexico, and Oklahoma). The proximity of each corridor to its partner was an essential criterion for inclusion of the pair in this data set; without detailed information on each pair, spatial proximity was felt to provide some control on other variables (such as zoning laws, terrain, and major travel patterns). Data from the 1990 Census of Population and Housing were used to compare the population-weighted averages of tract characteristics along these corridors. Two of the Texas pairs also fell into the Dallas-Ft. Worth metropolitan region, permitting analyses of employment characteristics along these corridors. The Dallas-Ft. Worth jobs data were made available by the region's planning organization, the North Central Texas Council of Governments (NCTCOG), permitting a look at employment by industrial sector and a census block-group distinction of corridor-relevant locations. The results of these comparisons are discussed here, and further details (including maps and actual data values) are provided in Kockelman et al. (Forthcoming) and Overman (2000).

Demographic information collected from each census tract included the following: median household income, per capita income, average household size, population density, percentage who drive alone to work, percentage who carpool to work, percentage who take public transit to work, percentage who bike to work, percentage who walk to work, average travel time to work, average private vehicle occupancy to work, percentage of population having a high school education or greater, percentage having a college education or greater, unemployment rate, percentage of population below poverty level, average resident age, average adult resident age (18+), and percentage of housing units that are multifamily structures. For each corridor, a population-weighted average of every variable was then computed. Differences of these averages between pairs were taken, and the statistical significance of these differences (when compared to no/zero difference) were evaluated (via a standard t-test).

Although the small sample size limits statistical significance of results, several differences were practically and statistically significant. Based on the differences that were found to be statistically significant at a 15 percent level (i.e., p-value $\leq 0.15$ ), census tracts near frontage roads appear to be associated with lower household incomes (averaging $\$ 3,800$ less per household, in 1990 dollars), lower population densities (513 fewer persons per square mile), lower percentages of bike trips to work (just $0.38 \%$ lower), lower vehicle occupancies for work trips (.08 persons per vehicle), and higher unemployment rates ( $2.3 \%$ higher) - relative to a similar/equivalent corridor constructed without frontage roads. These results suggest that inhabitants of frontage road corridors are not as well-to-do and are more automobile dependent than persons in the non-frontage road pairings. Frontage road corridors appear to be less desirable (due to an attraction of lower-income households) and less alternate-mode-friendly than non-frontage road corridors.

Though not statistically significant, the results also suggest that residents of frontage road corridors exhibit somewhat lower per-capita incomes, larger household sizes, more single- 
occupancy vehicle commuting, lower educational levels, greater incidence of poverty, older average age, and lower fractions of multifamily housing units (Overman 2000). With a larger sample size of such paired corridors in the U.S., such results may become statistically significant. Overall, however, the picture provided is incomplete; information on variables such as employment density and land-use patterns also would be helpful.

Using a GIS database of the Dallas-Fort Worth (DFW) metropolitan area, encompassing two corridor pairs, area employment densities were calculated for 17 different industrial classifications during the years 1990 and 1997. These data are presented in Table 3, and they are a strong proxy for land use in these corridors.

Table 3. Computed Average Corridor Employment Density by Employment Type in 1990 and 1997 (Jobs per Square Mile)

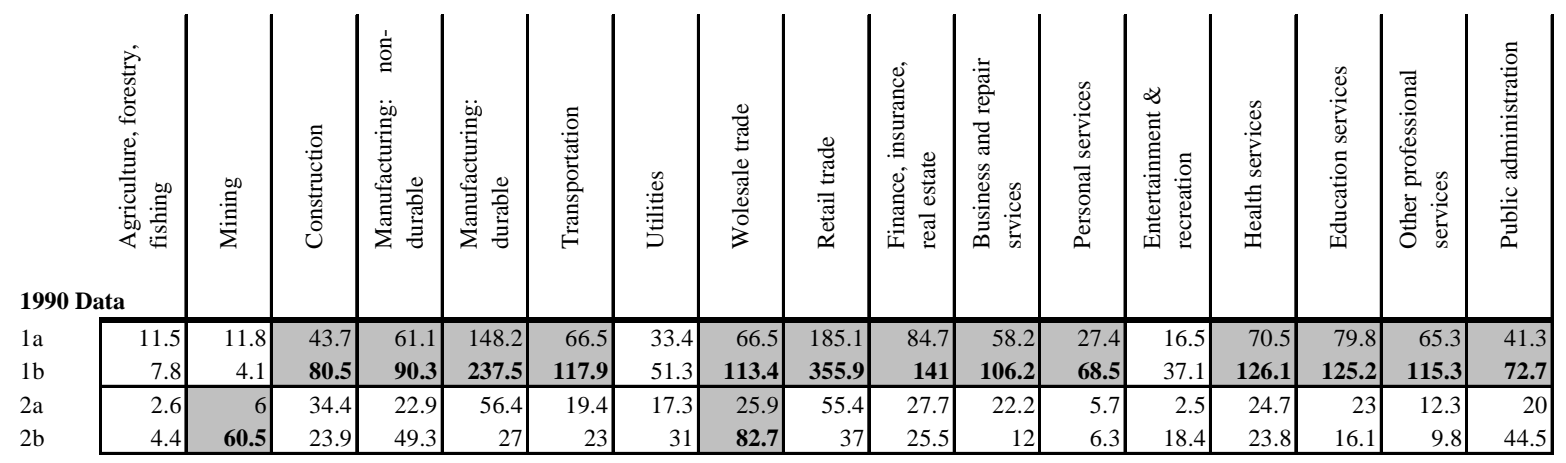

\begin{tabular}{|c|c|c|c|c|c|c|c|c|c|c|c|c|c|c|c|c|c|}
\hline \multicolumn{18}{|c|}{1997 Data } \\
\hline $1 \mathrm{a}$ & 15.9 & 14.8 & 65.8 & 76.3 & 183.7 & 84.7 & 37.6 & 84.7 & 249 & 111 & 84.9 & 39.1 & 21.5 & 102.4 & 109.2 & 95.7 & 53.6 \\
\hline $1 \mathrm{~b}$ & 11.2 & 4.5 & 98.8 & 98.1 & 257.8 & 130.2 & 51.3 & 123.4 & 408.3 & 161.3 & 134 & 80.1 & 41 & 161.4 & 149 & 146.8 & 82.9 \\
\hline $2 a$ & 3.1 & 5.6 & 37.4 & 23.2 & 53.5 & 21.6 & 16.6 & 28.1 & 60.8 & 30.8 & 27.5 & 7.4 & 2.8 & 29.3 & 25.2 & 16 & 20.5 \\
\hline $2 b$ & 7.2 & 5.2 & 67.6 & 26.9 & 51.5 & 31.4 & 24 & 36.3 & 99.3 & 45.2 & 33.9 & 15 & 7.9 & 24.7 & 29 & 23 & 12.6 \\
\hline
\end{tabular}

*Shaded figures represent instances when one corridor clearly "dominates" the other in terms of employment density in important/high-density categories.

The first DFW corridor pair in Table 3 includes I-20 from I-820 to Texas 360 (Corridor 1a, with frontage roads) and I-30 from I-820 to Route 157 (Corridor 1b, without frontage roads). The second consists of US 175 from Route 12 to Seagoville's city limit (Corridor 2a, with frontage roads) and I-20 at Union Pacific railroad crossing to a point 1/4-mile from the Seagoville Road ramp (Corridor $2 b$, without frontage roads). Corridor $1 b$, the second of these four, does not have frontage roads and clearly dominated the four cases in most of the employment density categories. To a lesser degree, Corridor $2 b$, the non-frontage road corridor in the second pair, dominated Corridor $2 \mathrm{a}$ in retail, wholesale, and non-durable manufacturing sector densities. In the 1990 data set, however, it was dominated by its frontage road partner in the durable manufacturing and retail trade sectors. These same two sectors were much higher in both Corridors $1 \mathrm{a}$ and $1 \mathrm{~b}$. This is likely due to corridor pair 1's location within the urbanized Mid Cities area of the Dallas-Fort Worth region, while corridor pair 2 is located at the southeastern edge of the urban fringe.

These results suggest a link between frontage roads and lower overall employment densities, which counters, to some extent, a perception that frontage road construction facilitates economic development along freeway corridors. However, land development is much more complex than this four-case study can illuminate. A source ${ }^{4}$ familiar with Case 1a noted that 
small portions are developing as commercial hot spots, but the area is traditionally zoned residential. Corridor 1b was a toll road until 1978; the area is home to Six Flags and the Ballpark at Arlington and has developed almost exclusively under commercial zoning. Thus, one would expect it to exhibit high job densities.

More research is needed to determine if there is a causal link between frontage road corridors, demographics, employment densities, and land uses. A greater number of corridors need to be compared, and these probably will come from outside Texas (since so few nonfrontage road freeway corridors exist within the state). A researcher able to access similar GIS databases to the Dallas/Fort Worth one utilized here may be able to draw more statistically and practically significant conclusions than those presented in this report. Moreover, a panel of cross-sections over time would better identify directions of causality (e.g., frontage roads may follow lower-income, lower-density locations, rather than causing their locations to exhibit these characteristics).

\section{OPERATIONAL ANALYSIS}

This research investigated the effectiveness of frontage roads as an element of controlledaccess facilities. Improper implementation of frontage roads reduces their attributed efficiency and may impair traffic flows on both the freeway and the frontage road itself. To understand under what geometric conditions the operation of frontage roads is problematic, an extensive literature review was conducted and a variety of corridor operations were simulated. The trafficanalysis software "CORSIM" (FHWA 1999) was used to evaluate the traffic operation of these scenarios.

Frontage roads offer some advantages for freeway operations. For example, they permit clear route-choice flexibility in cases of maintenance activities, crashes, or other emergencies. However, they may promote weaving maneuvers and intense ingress/egress activity from bordering land uses. Investigations by Pinnel (1963), Barnes et al. (1992), Nolin and Parham (1996), and Fitzpatrick et al. (1996) suggest a variety of design policies to enhance frontage road operations. Barnes et al. (1992) presented a case study on a section of I-610W where freeway flows improved, following the introduction of a collector-distributor system. However, it was found that the congestion shifted to loading and unloading points, such as intersections, creating even harsher consequences at several cross-street interchange locations. Based on their observations of various frontage road operations, Barnes et al. (1992) recommended that sufficient right of way exist, major cross-street spacing be generous, and existing intersection geometries be appropriate. They also recommended that ramps have one entrance lane and two exit lanes, interchange distances equal or exceed 3000 feet (915 meters), and weaving section lengths (on the frontage roads) be at least 1000 feet in length. In comparison with many Texas frontage-road corridors, these suggested dimensions are quite generous.

When ramps are frequent, the resulting weaving sections negatively impact safety and flow (Fitzpatrick et al., 1996). Lewis et al.'s (1999) findings indicated that decisions locating ramps in order to facilitate land development along roadway frontages (in 14 Texas case-study locations) could have very negative impacts on traffic flow. In some cases, growth and development along frontage roads created traffic volumes that exceeded the capacities of the ramps, frontage roads, and traffic signals during peak hours. Other cases suggested that dangerous weaving movements are encouraged when motorists wish to access driveways located close to ramps. Where engineers attempted to avoid such movements via geometric designs that 
created rather circuitous routes (to access certain driveways), motorists developed illegal and dangerous shortcuts in order to access these developments (Lewis, et al. 1999).

Fitzpatrick, Nowlin and Parham (1996) studied one-sided and two-sided weaving maneuvers (where one-sided weaving implies that ingress/egress points are only along the highway side of a frontage road, and two-sided weaving implies that these lie along both sides of the frontage road). Many factors influence traffic operations in such weaving sections; these include traffic volumes and capacities, ramp spacing, number of lanes, and design speeds. In particular, the effects of weaving length become more evident as traffic volumes increase (Fitzpatrick, Nowlin and Parham, 1996). Based on collected field data and NETSIM simulation, Fitzpatrick and Nowlin (1996a) plainly showed that weaving speeds fall as weaving volumes increase. Moreover, weaving sections below 200 meters in length may break down at relatively low traffic volumes, as compared to weaving sections longer than 200 meters. Based on correlations between weaving speed and weaving lengths, Fitzpatrick and Nowlin (1996a) therefore recommended that minimum weaving distances of 300 meters be provided.

The Highway Capacity Manual (2001) only explicitly considers weaving in the context of freeway design and operations. As Fitzpatrick, Nowlin and Parham (1996) recognize, sections of frontage roads that are influenced by weaving maneuvers between a freeway exit ramp and a downstream intersection possess two-sided weaving operations. For these sections, traffic exiting the freeway main lanes must change lanes to access exit points on the far side of a frontage road. Two-sided weaving is a very common and complex maneuver for frontage roads, but it is not specifically addressed in the Highway Capacity Manual.

The traffic-analysis software CORSIM (FHWA, 1999) was used to analyze delay for different traveler types (e.g., local and through) using a one-way frontage road-with-freeway network under different intensities of neighboring land uses and for variations in interchange/ramp spacing and parcel-point (i.e., driveway) spacing.

Three network cases were evaluated: a freeway with frontage roads and diamond interchanges, a freeway with frontage roads and X-type interchanges and a freeway with diamond interchanges but no frontage roads. Cases one and two are similar, except for interchange type. (Under X-type interchanges, weaving is shifted to the mainlanes and interchanges should be relatively frequent, to avoid circuity in local access via the mainlanes.) These two cases use a six-lane freeway supplemented on both sides by a one-way, three-lane frontage road and six-lane secondary arterials located roughly half a mile away. A six-lane underpass connects the non-freeway sub-network on both sides. Each network area was subdivided into roughly 18 different zones. CORSIM traffic volumes (including turn movements) were determined based on an origin-destination trip matrix among these zones, with the volumes attracted to and produced by every zone loaded on appropriate links. In order to ensure a fair comparison, aggregate network traffic volumes were the same for each of the three network cases. Access privileges alongside the freeway corridor are not permitted in case 3, due to an absence of frontage roads. Instead, all related access demand has been shifted to driveways along the cross-streets and parallel arterials in this case.

The study objectives were to assess the performance of each network case for several input variations (basic corridor geometry, interchange spacing and land use intensities) and to determine the impact of each input variable on each network. A comparison of the three case studies determined the conditions under which one case performs better than others (e.g., with 
lower average delays and higher speeds). The simulation focused primarily on delay (both stopped and total/travel delay ${ }^{5}$ ), and speed (especially on the freeway main lanes). These investigative efforts produced a quantitative assessment of when and where frontage-road provision is advisable. Moreover, the results of the simulations (such as the distribution profile of delays across traveler categories) and the flow observations permitted assessment of network performance and design options.

The three scenarios represent the most common types of freeway corridor networks relevant to this study. In all three cases parallel secondary arterials are located roughly $1500 \mathrm{ft}$. from the freeway median. This distance is far enough from freeway lanes to allow for significant corridor development but close enough to be considered as an alternative to frontage roads.

The study scenarios were analyzed for peak hour conditions. However, traffic demands were chosen to preclude heavy congestion and queue growth. If network elements became heavily congested, measures of effectiveness such as delay would increase with simulation time, substantially limiting the viability of post-simulation analyses. Three interchange spacings were used: $0.5,1$ and 2 miles. These reflect general practice for urban areas. Driveway spacings averaged 400 feet throughout the analysis. This number of driveways met the maximum number of links that the software was able to encode effectively.

Two distinct land use intensities (at peak hour) were analyzed: all residential use (0.5 trips/occupied dwelling unit) and all commercial development (4.9 trips/1000 ft ${ }^{2}$.) (ITE, 1997). For the case of residential development, it was assumed that each dwelling unit represents a 2000 $\mathrm{ft}^{2}$ area, parking and buildings covered $50 \%$ of the land each and the later were 3 stories high. For the commercial development case, $50 \%$ of the land was given to parking. In both cases, volume intensities were converted to trips per acre. These assumptions produced 10 trips/acre for residential use and 36 trips/acre for commercial use. These demands were then aggregated and loaded onto the driveways (both for egress and ingress).

While total traffic was maintained constant for every land use type across all scenarios, development layouts differed between frontage road and non-frontage road scenarios. Hence, parcel-point intensities (i.e., driveway volumes) differed from frontage road to non-frontage road scenarios. 50 and $200 \mathrm{vph}$ used each driveway under residential and commercial development assumptions for Scenario 3 (no frontage roads), while 35 and $130 \mathrm{vph}$ used each driveway under Scenarios 1 and 2.

A user equilibrium/shortest-path traffic assignment process was adopted for traveler route choices. This behavior provides reasonable path choices and prevents unreasonable results sometimes associated with all-or-nothing assignment processes. Origin-destination matrices involving both local and through traffic flows were then derived in an effort to control intersection traffic demands and turn movements so that each intersection would close to but below capacity (reflecting peak conditions). Based on intersection movements, calculations proceeded "backwards" (effectively) in order to determine the flows generated and received at each source-sink node. Site-oriented (i.e., local) traffic for residential cases varied with interchange spacings from $2,700 \mathrm{vph}(1 / 2$-mile spacing) to $6,600 \mathrm{vph}$ (2-mile spacing); for commercial cases these varied between 10,800 and $26,400 \mathrm{vph}$. In contrast, through traffic was held constant as levels of 10,800 in the residential case and 9,200 in the commercial case. (The lower commercial number reflected a need to avoid congestion, since more local traffic is 
generated under the commercial case.) These OD assumptions resulted in OD splits that are shown in Table 4.

Table 4. Origin-Destination Traffic Splits For All Scenarios

\begin{tabular}{|c|c|c|c|c|c|c|}
\hline \multicolumn{2}{|c|}{ Destination: } & & \multicolumn{2}{|c|}{$\begin{array}{l}\text { Freeway } \\
\text { Sections }\end{array}$} & $\begin{array}{l}\text { Major } \\
\text { Arterials }\end{array}$ & Driveways \\
\hline \multirow{2}{*}{\multicolumn{2}{|c|}{ Freeway Generated Traffic }} & & $\mathrm{R}$ & $80 \%$ & $5 \%$ & $15 \%$ \\
\hline & & & $\mathrm{C}$ & $64 \%$ & $4 \%$ & $32 \%$ \\
\hline \multirow{6}{*}{$\begin{array}{c}\text { Arterial Generated } \\
\text { Traffic (non- } \\
\text { driveway) }\end{array}$} & \multirow{6}{*}{ 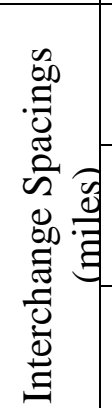 } & \multirow{2}{*}{$\ddot{n}$} & $\mathrm{R}$ & $40 \%$ & $10 \%$ & $50 \%$ \\
\hline & & & $\mathrm{C}$ & $12 \%$ & $1 \%$ & $87 \%$ \\
\hline & & \multirow[b]{2}{*}{-} & $\mathrm{R}$ & $32 \%$ & $1 \%$ & $67 \%$ \\
\hline & & & $\mathrm{C}$ & $8 \%$ & -- & $92 \%$ \\
\hline & & \multirow[b]{2}{*}{$\sim$} & $\mathrm{R}$ & $17 \%$ & -- & $83 \%$ \\
\hline & & & $\mathrm{C}$ & $5 \%$ & & $95 \%$ \\
\hline \multicolumn{2}{|c|}{ Driveway Generated Traffic } & & \multicolumn{2}{|c|}{$60 \%$} & $40 \%$ & -- \\
\hline
\end{tabular}

$\mathrm{R}=$ Residential Land Development

$\mathrm{C}=$ Commercial Land Development

As can be seen from Table 4, freeway traffic mainly traveled through the test corridor, with only $15 \%$ (for residential development) and $36 \%$ (for commercial development) exiting at ramps. In addition, it was assumed that no trips stayed within the test corridor. All drivewaygenerated trips were either destined for the freeway (60\%) or arterial streets $(40 \%)$.

Speed and delays were analyzed for freeways, ramps, and arterials under all three design scenarios, all three interchange spacings, and both land use types. Delay results are tracked by speed results (although inversely), so only speed results are shown here, in Tables 5 (for freeways) and 6 (for arterials).

Table 5. Freeway Performance (Speed)

\begin{tabular}{|c|c|c|c|c|c|c|}
\hline \multirow{4}{*}{ 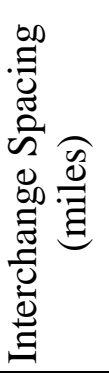 } & \multicolumn{6}{|c|}{ Land Use Type } \\
\hline & \multicolumn{3}{|c|}{ Mainly Residential } & \multicolumn{3}{|c|}{ Mainly Commercial } \\
\hline & No FR & FR D. & FR X. & No FR & FR D. & FR X. \\
\hline & \multicolumn{6}{|c|}{ Average Speed (miles per hour) } \\
\hline 0.5 & 58.4 & 57.4 & 58.2 & 26.6 & 52.4 & 54.0 \\
\hline 1 & 56.1 & 55.8 & 57.8 & 20.8 & 27.9 & 46.0 \\
\hline 2 & 58.0 & 47.7 & 57.7 & 11.0 & 17.9 & 7.1 \\
\hline
\end{tabular}


Note: Shaded cells identify significant congestion, conceptual Level of Service F.

For residential development, the peak-traffic results suggest that freeways without frontage roads perform as well as those with such supplemental systems. Those with diamond interchanges and frontage roads performed relatively poorly at high interchange spacings ( 2.0 miles). In contrast, under intense/commercial development, the value of frontage roads for freeway conditions seems clear. For medium interchange spacings (1 mile), $\mathrm{X}$ interchanges produce much higher freeway speeds and lower delays. Yet for the highest spacing ( 2 miles), diamond interchanges, with frontage roads, performed best.

Ramp performance was also investigated, and the associated delay and speed statistics suggested substantially better performance when frontage roads were in place. However, these conclusions are largely a product of the CORSIM network definitions and geometries, because without frontage roads, ramps are connected to at-grade intersections at the crossing street. The intersection causes ramp delay because a non-zero fraction of the exit ramp traffic must stop at the intersection. The provision of frontage roads permit stored ramp traffic to load onto the frontage roads where more storage space is available. This will inevitably enhance ramp performance. Table 6 tracks the performance of corridor arterials (i.e., the speeds on all roadway links other than freeway lanes and ramps).

Table 6. Arterial Performance (Speed)

\begin{tabular}{|c|c|c|c|c|c|c|}
\hline \multirow{4}{*}{ 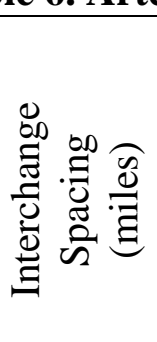 } & \multicolumn{6}{|c|}{ Land Use Type } \\
\hline & \multicolumn{3}{|c|}{ Mainly Residential } & \multicolumn{3}{|c|}{ Mainly Commercial } \\
\hline & No FR & FR D. & FR X. & No FR & FR D. & FR X. \\
\hline & \multicolumn{6}{|c|}{ Average Speed (miles per hour) } \\
\hline 0.5 & 18.7 & 20.1 & 21.2 & 5.0 & 6.9 & 7.3 \\
\hline 1 & 18.6 & 20.1 & 21.8 & 4.4 & 5.0 & 3.7 \\
\hline 2 & 11.6 & 9.4 & 16.7 & 4.7 & 5.2 & 4.2 \\
\hline
\end{tabular}

Note: Shaded cells identify significant congestion, conceptual Level of Service F.

Under assumptions of residential development, arterial speed (and delay) statistics suggest that increased interchange frequency (via decreased spacings) improves arterial performance, by moving travelers onto freeways faster and/or moving them more directly to their local destinations. These results also suggest that the provision of frontage roads enhances arterial performance under residential development conditions. This result is not too surprising, given that frontage roads add arterial lane miles to the corridor, substantially supplementing the local network.

Under assumptions of intense commercial development, arterial speeds were rather dismal under all corridor scenarios. Frontage roads with a diamond design seem somewhat 
preferred, but the simulated arterial roadways were so congested that such speed differences may be difficult to discern by actual travelers.

As a final note on operations, $\mathrm{X}$ interchanges appear preferable to diamond interchanges when assuming residential development. $X$ interchanges tend to reduce frontage road weaving conflicts and at-grade intersection traffic demand on frontage road sections, which may explain why these perform slightly better. However, $X$ interchanges require the presence of frontage roads as well as relatively frequent interchange access (to reduce route circuity for freeway users trying to access adjacent land uses). More frequent interchanges can also negatively impact road speeds (though they do enhance access), so $\mathrm{X}$ interchanges cannot be considered the solution to many situations.

\section{COST COMPARISONS}

To determine the relative costs of providing freeway facilities with and without frontage roads, total corridor costs were assembled here by construction, land, and access costs. Cost information from a number of sources was used to analyze a series of distinct scenarios, both with and without frontage roads. Frontage road provision requires additional construction expense, as well as additional expense associated with right-of-way costs. However, freeways with frontage roads avoid the significant cost of access acquisition. This work allowed estimation of the level of access costs at which the provision of frontage roads would become less costly, as well as determination of the relative costs of providing or excluding frontage road configurations in new-location facilities.

Construction costs were determined using data made available by the Texas Department of Transportation's (TxDOT) Design Division in construction of recent projects along U.S. 59, IH-45, U.S. 83, and Spur 330. TxDOT's five-year averages of construction costs across all newlocation freeway and freeway upgrade projects were also taken into consideration during this phase of the research. Monetary costs of construction projects were divided into costs associated with mainlanes and those associated with frontage roads. Conversations with F. Doug Woodall, TxDOT's Field Coordination Section Director, Design Division (Woodall, 2001a and 2001b), added more specifics, as to ramp, utility movement, and drainage costs.

Interviews with a private assessor frequently contracted by TxDOT (Hornsby 2000), revealed that rural land values likely vary from $\$ 0.15$ to $\$ 0.30$ per square foot, and that urban land values may fall anywhere between $\$ 5.00$ and $\$ 20.00$. These asssumptions were verified by a study of appraised land values in the Austin area, as provided by the Travis Central Appraisal District (TCAD 2001). These land costs were then used to calculate the total cost of purchasing right of way for the facility. Using TxDOT's Austin District's standard right-of-way (ROW) guidance on widths (2000), full build-out scenarios were assumed to require ROW widths of 150 feet for a rural 4-lane freeway without frontage roads to 400 feet for an urban 10-lane freeway with 6 lanes of frontage road. For facility expansions, ROW width additions ranged from no additional ROW (for 2 new mainlanes) to 160 feet (for 4 new mainlane and 6 frontage road lanes). (Please see Kockelman et al. [Forthcoming] for additional details on assumptions used here.)

New location facilities without frontage roads also involve the additional cost of paying damages (or purchasing remainders) of properties divided by the new facility, where one part of the parcel would be left without access. This was estimated to add approximately 10 percent to the cost of land acquisition on such projects (Toner, 2001). 
Access costs were calculated using the data in Westerfield's (1993) and Gallego's (1996) Texas studies. These values varied widely; costs per linear foot of access taken ran as low as $\$ 0$ and as high as $\$ 2,421$ (all costs expressed in 2001 dollars). The mean access cost per linear foot was $\$ 497$, with a standard deviation of $\$ 715$. Further discussions with TxDOT's Austin District Right of Way Director revealed that such a variation is common, and that there really is no standard access valuation (Harwood, 2001).

In calculating the cost estimates, highs and lows for both urban and rural scenarios were used. In the rural scenarios the $25^{\text {th }}$ percentile $(\$ 11.47)$ was the low parameter, while the mean (\$496.80) was the high parameter. While such a cost may seem entirely unrealistic for rural access, which is typically quite low, it was intended to also encompass some of the suburban and ex-urban access costs that are not classifiable as urban, per se. In the urban scenarios the mean (\$496.80) was the low parameter, and the $75^{\text {th }}$ percentile was the high parameter $(\$ 799.04)$. Observed access costs for individual parcels may exceed these averages considerably, but averages over a stretch of road would likely be within these observed parameters.

Access costs were only applied in those scenarios that did not include frontage roads and where previously those lot owners had had access to the facility (i.e., existing/old location freeways). Access costs PER MILE were obtained by multiplying the cost PER linear foot by 10,560 feet (assuming that access needed to be purchased for each linear foot on boths side of the upgraded facility). Threshold access costs were also back-caculated from the scenarios to determine the critical cost that would determine the low-cost alternative (i.e., frontage roads or no frontage roads) in an upgrade project.

Three general project cases were considered: provision only of mainlanes (case Type A), mainlanes plus frontage roads (Type B), and a lower number of mainlanes plus frontage roads (Type C). The first two cases were compared on the basis of the same number of mainlanes, so the first clearly enjoyed lower construction and land acquisition costs (but necessitated access costs); the third case included fewer mainlanes, in order to recognize the frontage roads' contribution to corridor capacity (two mainlanes were removed for four frontage road lanes). Three improvement/upgrade scenarios and five new-location/full-build-out scenarios were considered for each of these three cases. Moreover, interchange spacings were varied from 0.5 to 1.0 to 2.0 miles, land values and access cost assumptions (both high and low) were distinguished by rural versus urban settings. ${ }^{6}$ Construction cost assumptions were either high or low. Cost assumptions are shown in Table 7.

Table 7. Cost Assumptions (2001 dollars)

\begin{tabular}{|l|l|l|}
\hline Item & Low Estimate & High Estimate \\
\hline Mainlane, per usable lane mile & $\$ 478,000$ & $\$ 1,097,000$ \\
\hline Frontage, per usable lane mile & $\$ 339,000$ & $\$ 507,000$ \\
\hline ROW acquisition, per square ft, rural & $\$ 0.15$ & $\$ 0.30$ \\
\hline ROW acquisition, per square ft, urban & $\$ 5.00$ & $\$ 20.00$ \\
\hline Rural access purchase, per linear foot & $\$ 11.50$ & $\$ 497.00$ \\
\hline Urban access purchase, per linear foot & $\$ 497.00$ & $\$ 800.00$ \\
\hline Cost per Ramp (4 ramps per interchange) & $\$ 25,000$ & $\$ 75,000$ \\
\hline
\end{tabular}

For the new-location long-range, full build-out scenarios, cost ratios were computed between scenarios of Type A and Type B, and then between those of Type A and Type C. As 
expected, corridors without frontage roads reduced total project costs significantly, since access rights costs did not require consideration/inclusion. In urban areas, cost-ratio estimates started at 0.58 , for moderate-size, low-unit-cost project comparisons of Types B to A; these rose to 0.99 , for large-size high-unit-cost project comparisons of Types $\mathrm{C}$ to $\mathrm{A}$. In rural areas, ratios ranged from 0.65 to 1.12 , and these two ratio extremes involved essentially the same project types/sizes. Here, the "moderate-size" project means addition of six mainlanes under Type A, six mainlanes and six frontage road lanes under Type B, and four and four under Type C. The "large-size" project types involve ten, ten and six, and eight and four, mainlanes and frontage road lanes under the three cases, respectively.

In the case of the facility upgrade/expansion scenarios, it was more useful to determine the level of access cost beneath which it would be favorable to purchase access rather than construct frontage roads. Both pairs of upgrade access-cost-threshold extremes occurred at the larger project scenarios (i.e., the three cases involving either addition of 4 mainlanes [Type A], addition of four mainlanes and six frontage road lanes [Type B], and addition of two mainlanes and four frontage road lanes [Type $\mathrm{C}$ ]). In urban environments, these values were computed to range from $\$ 88$ (per linear foot of access) in low-cost comparisons of cases one and three, to $\$ 1,288$ for high-cost comparisons of cases one and two. For facility upgrades/expansions in rural areas, the threshold access costs started at effectively zero (actually negative \$13) for high-cost comparisons of cases one and three, to $\$ 303$, for high-cost comparisons of cases one and two. Since the access-right cost estimates of Westerfield and Gallego suggested first and third quartiles of $\$ 497$ and $\$ 799$ per linear foot, the results of 24 such comparisons suggest that most upgrade cases would favor no provision of frontage roads, from a total project cost perspective even when no "capacity credit" was given for such lanes. It was only in under the high-cost comparisons in urban areas when no capacity credit was given that the threshold access costs (needed to make access purchase uneconomical) rose to very high levels that would likely exceed actual access rights costs. Interestingly, it is in these same locations and cases that development intensities and traffic are likely to be so high that the provision of frontage roads would make additional sense from other perspectives, not just, perhaps, a cost perspective.

\section{CONCLUSIONS}

The decision to design freeways with or without frontage roads poses a variety of questions. These relate to legal rights and responsibilities, planning and land development, safety and access control, traffic flow and operations, construction costs, and other areas. This work summarizes a comprehensive investigation of frontage roads via legal, functional, financial, and other comparisons of freeway corridors with and without such roads. While many frontage road decisions are likely to be highly site-specific (depending, for example, on present land uses alongside freeway corridors, local zoning designations, expectations of future development, public sentiment, and topographical, network, and other design constraints), the results of this work should better enable departments of transportation and local jurisdictions to objectively weigh the costs and benefits of frontage roads; the objective is identification of policies and practices that aid community objectives through better freeway design.

This extensive study's review of the literature, case studies, corridor pair analysis, operational analysis, and cost analysis should permit more informed decisions regarding the use of frontage roads as an element of controlled access facilities. All together, the efforts represented in this report aimed to produce a comprehensive assessment of the benefits and costs entailed by frontage road provision - as well as to suggest optimal design strategies. 
The review of literature related to frontage roads considered a variety of issues, including access-right valuation, access policies, and operations. It also highlighted issues of reasonable access, alternatives to frontage roads, corridor preservation, ramp location and spacing, merge lengths, and access-point densities. Overall, it suggests that a wide variety of options are available to agencies for limiting access to and improving flow and safety along freeway corridors.

The survey of state DOTs indicates that a state's tendency to build frontage roads depends both on past access policies within the state, which depend heavily on legislation, and formal policy guidelines that specify the provisions under which a frontage road will be provided. Moreover, the roadway geometry associated with frontage roads in other states was in many cases quite different from typical Texas designs. Backage roads, where development was allowed to occur on both sides of the roadway, were used by several states; generous ramp-tosignal distances were required by several policy guidelines; and development adjacent to the ramp-frontage road interface (to prevent dangerous weaving maneuvers) was generally much more restricted than in the state of Texas, where most frontage roads are found.

The twelve case studies of Austin-area frontage roads indicated that increased access density along frontage roads contributes substantially to crash and injury incidence. Thirteen corridor pairs across five states were selected based on their proximity to one another within an urbanized area and the presence of frontage roads alongside one but not the other. The results presented here suggest that land near frontage roads exhibits lower household incomes, lower population densities, lower percentages of bike trips to work, lower vehicle occupancies for work trips, and higher unemployment rates - relative to its control corridor, constructed without frontage roads. Though not statistically significant, the results also suggest somewhat lower percapita incomes, larger household sizes, more single-occupant-vehicle (SOV) commuting, lower educational levels, and more poverty in corridors utilizing frontage roads. Moreover, based on a detailed comparison of two corridor pairs in the Dallas-Ft. Worth region, for which employment data by industrial sector and census block group are available, higher commercial intensities existed along the two corridors without frontage roads. The difference was particularly dramatic in one of the two comparisons. It suggests that zoning, rather than frontage road provision, guides development of freeway corridors.

The operational analysis of freeway systems with and without frontage roads demonstrated that frontage roads may improve the operation of freeway mainlanes in intensely developed areas, but not in moderately developed areas (i.e., purely commercial versus purely residential). Arterials also performed better when frontage roads were provided. However, these operational analyses compared corridors without frontage roads to those where fully six lanes of frontage roads were purely added - without removing any freeway lanes. Clearly, network capacity was expanded, subsidizing, in effect, the local network. So it is quite understandable why the arterial links and in some cases the freeway lanes performed better after the addition of frontage roads.

The financial costs associated with frontage road facilities were found to be considerably higher than those associated with non-frontage road facilities. Such comparisons favored nonfrontage road facilities both when frontage roads were considered to only provide access and when it was assumed that their purpose was also to carry additional capacity. In some areas where land values are extremely high (e.g., central Austin), frontage roads may preclude purchase of very high access costs, making them cost competitive. However, such savings would likely only be evident on relatively short projects bisecting very high land value areas. 
The analyses presented here represent many avenues of study not previously attempted. It is hoped that these results, in addition to efforts by other researchers, will assist in constructing a solid, formal policy for all states and regions to follow in providing access along new and existing freeways in the decades to come.

\section{ACKNOWLEDGEMENTS}

The authors wish to acknowledge the financial support of the Texas Department of Transportation, and the technical contributions and time and effort of many of the Department's excellent employees. These include F. Douglas Woodall, Ed Collins, Julie Brown, Al Luedecke, Charlie Sullivan, Robert Harwood, Darcie Shipull, and Don Toner. Information provided by Travis (County) Central Appraisal District; Buck Ritts, at the Texas Attorney General's office; and Paul Hornsby, of Frederick and Hornsby Inc., was also very useful to this work.

\section{ENDNOTES}

${ }^{1}$ High variances indicated that observed vehicles traveled at a variety of different speeds, while lower variances indicated vehicles generally traveling closer to the mean corridor speed. This variable was estimated via the following formula:

$$
\sigma_{\text {speed }}^{2}=\sum_{i=1}^{N} \frac{\left(\text { speed }_{i}-\text { speed }_{\text {avg }}\right)}{N-1}
$$

2 The I-35 northbound at Parmer Lane section was the only observation without any access points, but there may be such connections made in the future. The MoPac (Loop 1) Southbound at Capital of Texas Highway section offered no intersecting driveways. It is bordered by a thin parcel of University of Texas-owned land which buffers the frontage road from development activity (though successful and intense development has occurred nearby, along the intersecting Capital of Texas Highway).

${ }^{3}$ Models without the Speed Variance variable but with the Incidence of Speeding variable were also tested, but these produced the lowest adjusted R-squared values of any considered.

${ }^{4}$ This source is Charlie Sullivan, Team Supervisor in the Transportation Planning and Programming Division of TxDOT.

${ }^{5}$ Papacostas and Prevedouros define travel delay as "difference between the time a vehicle passes a point downstream of the intersection where it has regained normal speed and the time it would have passed that point had it been able to continue at its approach speed" while stopped delay "is the time duration of "substantially standing still"' (2000, p.187) while waiting in queue at a signalized intersection approach. Substantially standing still is usually taken to be $3 \mathrm{mi} / \mathrm{h}$ or less. And empirical results suggest that division of total delay by 1.3 results is the stopped delay.

${ }^{6}$ Note that unlikely situations have been removed from the analysis; these include case-scenario-design-cost combinations that were rural and had 0.5-mile interchange spacings or rural combinations with high access and/or high land costs. 


\section{REFERENCES}

AASHTO 1995. “A Policy on Geometric Design of Highways and Streets, 1994”. American Association of State Highway and Transportation Officials. Washington D.C.

AASHTO Quarterly. 1992. “NJ Enacts Extensive New Controls on Highway Access.” AASHTO Quarterly 71 (4): 5.

American Association of State Highway and Transit Officials. 1990. Report of the AASHTO Task Force on Corridor Preservation. Washington, D.C.: AASHTO (July).

American Association of State Highway Officials. 1961. A Guide for the Application of Frontage Roads on the National System of Interstate and Defense Highways. Washington, D. C.

Barnes, K., Hanks, J., and Mounce, J. 1992. "Considerations in the Application of CollectorDistributor Designs for Improving Mainlane Freeway Operations.” Texas Transportation Institute Research Report 1232-16 (October).

Bass, Patricia L., Crawford, James A., Hall, Kevin M., Farnsworth, Stephen F., Pugh, David L. 1996. "Corridor Preservation: A Review of Strategies for Texas." Texas Transportation Institute Research Report 1495-1F.

Bowman, Brian L., and Vecellio, Robert L. 1994. "Effect of Urban and Suburban Median Types on Both Vehicular and Pedestrian Safety." Transportation Research Record No. 1445.

Bowman, Donald L., and Rushing, C. Colin. 1998. "Access Management: Transportation Policy Considerations for a Growing Virginia." Charlottesville, VA.: Virginia Transportation Research Council.

Eisdorfer, A.J. 1997. "New Jersey State Highway Access Management Code to Preserve Corridor Accessibility and Manage Economic Growth." Presented to Institute of Transportation Engineers 67th Annual Meeting. Boston, MA.

FDOT. 1999. "Ten Ways to Manage Roadway Access in Your Community." Center for Urban Transportation Research, University of Southern Florida.

FHWA. 1976. America's Highways: 1776-1976. Washington, D.C.: United States Department of Transportation, Federal Highway Administration.

FHWA. 1992. "Safety Effectiveness of HIghway Design Feastures, Volume 1." US DOT, Federal Highway Administration. Washington, D.C. (November)

FHWA. 1999. CORSIM, Version 4.2. Federal Highway Administration, U. S. Department of Transportation (Distributed through McTrans, University of Florida). 
Fitzpatrick, K., and Nowlin, R. 1996a. "One-Sided Weaving Operations on One-Way Frontage Roads." Transportation Research Record 1555. TRB: Washington, D.C.

Fitzpatrick, K., and Nowlin, R. 1996b. "Two-Sided Weaving Operations on One-Way Frontage Roads." Texas Transportation Institute Research Report 1393-2 (June).

Fitzpatrick, K., Nowlin, R., and Parham, A. 1996. "Procedures to Determine Frontage Road Level of Service and Ramp Spacing." Texas Transportation Institute Research Report 1393-4F (August).

Gallego, Amado Vélez. 1996. "Interrelation of Land Use and Traffic Demand in the Estimation of the Value of Property Access Rights." Thesis for Masters of Science in Civil Engineering, The University of Texas at Austin.

Geiger, D., Michel R., Levinson, H., Gluck, J., Micehl, R., Demosthenes, P. 1996. “An Overview of Access Management at Selected State DOTs." Proceedings of the Second National Access Management Conference; Vail, Colorado. Sponsored by the Transportation Research Board, Federal Highway Administration and Colorado Department of Transportation.

Greenberg, Mike. 1999. “Texas Learns to Build Freeways.” San Antonio Express News (November 10).

Harwood, Robert. 2001. Right of Way Director. Texas Department of Transportation, Austin District. Personal Interview (March 27).

Hornsby, Paul. 2000. Principal partner of Frederick and Hornsby, Inc. Austin, Texas. Personal Interview (September 11).

IDOT. 1995. Iowa Primary Road Access Management Policy. Iowa Department of Transportation. Ames, Iowa (July).

Institute of Transportation Engineers (ITE). 1997. Trip General Manual, $6^{\text {th }}$ edition. ITE, Washington, D.C.

Interim Report to the $73^{\text {rd }}$ Texas Legislature. 1992. Committee on Transportation, David Cain, Chairman (September).

Interim Report to the $75^{\text {th }}$ Texas Legislature. 1996. Committee on Transportation, Clyde Alexander, Chairman (December).

ITE. 1997. Trip General Manual, $6^{\text {th }}$ edition. Washington, D.C.

Kaltenbach, Henry J. 1967. “The Elastic Right - Access.” The Appraisal Journal, American Institute of Real Estate Appraisers, 35 (1): 9-16 (January).

Kockelman, K., Overman, A., Peterman, J., Madi, M., Machemehl, R., and Handy, S. 1999. "Investigation of the Impact of Frontage Roads as an Element of Controlled Access Facilities". 
Center for Transportation Research, The University of Texas, at Austin. TxDOT Project Report 0-1873-1.

Kockelman, K., Machemehl, R., Overman, A., Sesker, J., Madi, M., Peterman, J., and Handy, S. Forthcoming. "The Impact of Frontage Roads as an Element of Controlled Access Facilities: A Comprehensive Assessment." Center for Transportation Research, The University of Texas, at Austin. TxDOT Project Report 0-1873-2.

Kors, L.D. 1996. “Access Management Project of British Columbia.” Second National Access Management Conference; Vail, Colorado. Sponsored by the Transportation Research Board, Federal Highway Administration and Colorado Department of Transportation.

Kweon, Y-J., Kockelman, K.M. Forthcoming. "Overall Injury Risk to Different Drivers: Combining of Exposure, Frequency, and Severity Models." Submitted to the Transportation Research Board's $81^{\text {st }}$ Annual Meeting, January, 2002.

Lee, Clyde. 2000. Professor Emeritus, University of Texas at Austin. Personal interview (March 6).

Lemly, J.H. 1956. Economic Consequences of Highways By-passing Urban Communities. Atlanta, GA.: Georgia State University.

Lewis, C.A., Buffington, J.L, Vadali, S.R. and Goodwin, R.E. 1997. "Land Value and Land Use Effects of Elevated, Depressed, and At-Grade Level Freeways in Texas." Texas Transportation Institute Report 1327.

Lewis, Carol A., Handy, Susan, and Goodwin, Ronald E. 1999. "Evaluation of the Effects of Ramp Location on Land Use and Development." Research Report 0-1762-3, Texas Department of Transportation (May).

Lloyd, M.D. 1995. "Assessment of TRAF-NETSIM for Analyzing Arterial Weaving Between Ramp Terminal and Cross Streets." Thesis for Masters of Science, in Civil Engineering Texas A\&M University, College Station, Texas.

Long, Gary, Gan, Cheng-Tin, Morrison, Bradley S. 1993. "Safety Impacts of Selected Median and Access Design Features: Final Report." University of Florida, Transportation Research Center.

Luedecke, Alvin R. 2000. Director of Transportation Planning and Programming. Texas Department of Transportation. Personal interview (August 18).

Madi, Marwan. 2001. "Investigation of the Impact of Frontage Roads as an Element of Controlled Access Facilities." Thesis for Masters of Science in Civil Engineering, The University of Texas at Austin.

Messer, C.J., Whiston, R.H., and Carvell, J.D. Jr. 1974. “A Real-Time Frontage Road Progression Analysis and Control Strategy”. Transportation Research Record No. 503: 1-12. 
Michel, R.M., Levinson, H.S., Falcocchio, J.C., Chew, J., and Court, T. 1996. “Access Management Practices in Connecticut." Second National Access Management Conference; Vail, Colorado. Sponsored by the Transportation Research Board, Federal Highway Administration and Colorado Department of Transportation. pp. 317-323.

Netherton, Ross D. 1963. Control of Highway Access. Madison, WI: The University of Wisconsin Press.

Newsome, Pamela J. 1997. “Access Management: Documenting Practices External to Minnesota." St. Paul, Minn.: Office of Research Services, Minnesota Dept. of Transportation, IRIS report.

OKI COG. 1986. Access Management: A Policy for Local Communities. Prepared by the OhioKentucky-Indiana Regional Council of Governments.

Overman, Aaron. 2000. "Frontage Roads in Texas: Issues and Impacts." Thesis for Masters of Science in Civil Engineering, The University of Texas at Austin.

Pant, Prahlad D., Sadrul Ula, Md., Liu, Yuejiao 1999. "Methodology for Assessing the Effectiveness of Access Management Techniques." Columbus, Ohio: Ohio Dept. of Transportation.

Papacostas, C.S., and Prevedouros, P.D. 2001. Transportation Engineering and Planning, Third Edition. Upper Saddle River, New Jersey: Prentice-Hall.

Peterman, J.L. 2000. "The Effect of Land Development on the Perofrmance of Frontage Roads at Ramp Intersections." Thesis for Master's in Community and Regional Planning, The University of Texas at Austin.

Pinnel, Charles and Tutt, Paul R. 1963. Evaluation of Frontage Roads as an Element of Urban Freeway Design. Texas Highway Department, Report 62-3. Presented to Highway Research Board (January).

Sharma, S., and C.J. Messer. 1994. "Distance Requirements for Ramp Metering: Interim Report.” FHWA/TX-95/1392-5. Federal Highway Administration, U.S.

Stokes, Robert W. 1995. “Corridor Preservation for Two-Lane Rural Highways.” ITE Journal 65 (6): 14-17.

TCAD. 2001. On-line database of appraised property in the Travis County area. at http://www.traviscad.org/search.htm, accessed 2001.

Texas Performance Review (State Comptroller's Office). 1991. Breaking the Mold. Volume 2, Part I, Transportation, Recommendation TR 10 (July).

Texas Transportation Commission. 2001. Minute Order 108544 (June 28). 
Toner, Donald. 2001. ROW Administrator, Texas Turnpike Authority. Personal Interview (August 2).

TRB. 1997. Highway Capacity Manual, Special Report 209, National Research Council. Washington, D.C. (1997).

TxDOT. 1984. Highway Design Division Operations and Procedures Manual. Texas Department of Transportation (formally then titled the State Department of Highways and Public Transportation or "SDHPT"), Highway Design Division. Austin, Texas.

TxDOT. 1996. Regulations for Driveways to State Highways. Texas Department of Transportation (August).

TxDOT. 2000. Austin District Standard Right of Way Width. Texas Department of Transportation. Austin, Texas.

U.S. DOT, Federal Highway Administration. 1999. CORSIM, Version 4.32. United States Department of Transportation (October).

Vance, John C. 1988. "Rights of Abutting Property Owner Upon Conversion of UncontrolledAccess Road into Limited Access Highway." Selected Studies in Highway Law 2: 936-N339 to 936-N361.

Vernon's Texas Statutes and Codes Annotated. 1994. Saint Paul, Minnesota: West Publishing Co.

Vorster, H. D. and Joubert, H.S. c1997. “Access Management in Practice: The Pretoria Experience." Proceedings of the Third International Symposium on Intersections Without Traffic Signals, Portland, Oregon, U.S.A. Moscow, Idaho: University of Idaho, National Center for Advanced Transportation Technology.

WDOT. 1998. "Access Management Policy, Wyoming." U.S. Bureau of Land Management. Washington, D.C.

Westerfield, Heidi. 1993. "A Model for Estimating the Value of Property Access Rights." Thesis for Masters of Science in Civil Engineering University of Texas at Austin.

Westerman, H.L. 1990. "Roads and Environments.” Australian Road Research 20 (4): 5-23.

Williams, Alan W. 1993. "Transport, Rights-of-Way and Compensation: Injurious Affection from an Economic Perspective and Some Australian Evidence of Freeway Impacts."

International Journal of Transport Economics 20 (3): 285-94.

Williams, K. and Forester, J. R.. 1996. NCHRP Synthesis 233: Land Development Regulations that Promote Access Management. National Cooperative Highway Research Program, Transportation Research Board. Washington, D.C.: National Academy Press. 
Williams, Kristine M., Rudge, Daniel E, Sokolow, Gary, and Eichin, Kurt. 1994. "Model Land Development and Subdivision Regulations that Support Access Management." Center for Urban Transportation Research, University of South Florida, Tampa, Florida (January).

Woodall, Fred Douglas. 2000. Field Coordination Section Director. Texas Department of Transportation. Personal interview (August 18).

Woodall, Fred Douglas. 2001a. Field Coordination Section Director. Texas Department of Transportation. Personal Interview (February 5).

Woodall, Fred Douglas. 2001b. Field Coordination Section Director. Texas Department of Transportation. Personal interview (April 18). 